\title{
Erie Pier: Finding Sustainable Markets For Dredged Materials
}

Rodger L. Brannan, University of Minnesota Duluth, USA James Skurla, University of Minnesota Duluth, USA

Stephen Castleberry, University of Minnesota Duluth, USA

\begin{abstract}
The Port of Duluth is a public corporation charged with maintaining the infrastructure and facilities that allow shipping companies to profitability move large quantities of commodities through the port to their destination. One essential element of ongoing operations is dredging; that is maintaining adequate depth for the very large bulk carrier ships that frequent the Port of Duluth. A major challenge is finding a place to store the dredged materials. A number of Federal and State regulations restrict how and where the materials can be stored. In the Port of Duluth space to store the materials is quickly disappearing. Without a place to store the materials, both dredging and overall port operations will have to be seriously curtailed. The port's management is searching for low cost alternatives to the contained disposal facility it is now using. Presently, sustainable markets are being developed as an alternative to storing dredged materials at the port's facility.
\end{abstract}

Keywords: Cost; Dredging; Markets; Operations; Regulations; Sustainable

\section{INTRODUCTION}

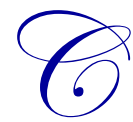

ost of production is a major concern for any company that wants to maintain a healthy profit margin. This is certainly true for those firms that actually operate shipping companies out of the Port of Duluth/Superior. Shipping companies strive to minimize operating costs by maximizing cargo loads on the vessels that carry the cargo in and out of the port. An obscure but major factor in allowing firms to maximize cargo carried is the draft or clearance between the ships keel and the lake bottom. This clearance is impacted by a couple of variables. One factor is climate. Rain and snowfall affect the water level of Lake Superior. One inch of clearance can have a big impact on the amount of cargo carried by the vessels over a shipping season. However, it is a random variable and the companies cannot control the amount of precipitation that falls in the Lake Superior watershed. However, one factor that can be controlled and that affects the clearance is the amount and location of dredging that takes place in the Port of Duluth/Superior.

Dredging is an enormous factor in the profitable operations of shipping firms utilizing the port. However, there is a problem brewing that will affect the amount of dredging that can take place. Within the next five years, the port will no longer have a place to store the materials dredged from the shipping channels. Erie Pier, the port's contained disposal facility (CDF) is quickly running out of room to store the dredged materials.

\section{BACKGROUND}

Dredging in the Port of Duluth/Superior is the responsibility of the Army Corps of Engineers (ACE). They get funding from Congress and the Harbor Maintenance Tax to conduct dredging. They have to decide how much needs to be done in the respective ports around the country. They then allocate funds to ACE districts throughout the country to take care of needed dredging. The amount of dredging that can take place each year is a function of funding and politics. The amount of dredging that needs to take place each year is a function of geology and 
geography. It is based on the amount of silt and sand ${ }^{1}$ that the rivers push down into the port. In the Port of Duluth shipping companies do not explicitly pay for dredging. They pay indirectly in the form of taxes and fees paid to the federal government. However, shipping companies must pay a docking fee to the Port Authority of Duluth whenever one of their ships enters the harbor and docks at a pier to off load its cargo. This money is used to maintain the infrastructure of the port facilities. The Port maintains and operates with the ACE a confined disposal facility (CDF); called Erie Pier. Erie Pier is where they place all of the dredged materials they cannot put anywhere else. The problem is not with the dredging, but what to do with the dredged materials after they come out of the bay. In the past they have sometimes been able to pump dredged materials to the beaches to replace what has been lost due to erosion. That is what is called call beach nourishment. Sometimes it has been used to help build port facilities. However, most of the time the ACE will put the dredged materials on a barge and then transport the material to Erie Pier. Erie Pier is really a tiny peninsula sticking into the bay. It was never meant to hold the amount of dredged materials that have been stored there. The ACE has been able to raise the dikes surrounding it a couple of times, but cannot do that anymore. The port is running out of time and space for the dredged materials that come out the bay each year. The Port of Duluth/Superior will have to close Erie Pier in about 5 years. If they cannot come up with an alternative place to store or place the dredging they will eventually have to shut down the ports of Duluth and Superior. That would be a devastating economic blow to the area.

The sand and silt are not considered to be toxic materials. In other parts of the country dredged materials are in fact found to contain many toxic materials. Erie Pier is used to store mostly the fine silt-like material (hereafter referred to as silt) dredged from the bottom of the port. The sand or coarse material is generally taken immediately by contractors (at no cost to the contractors). Erie Pier has been used to store basically clean silt materials that cannot be placed anywhere else.

In Minnesota and Wisconsin, the dredged materials cannot be dumped into Lake Superior. The materials can be used to replenish beaches and to build or shore up port facilities. Erie Pier is just a few years from reaching its maximum capacity. Politically, no one will allow another CDF to be built in either Minnesota or Wisconsin. Engineers for both the port and the ACE estimate that Erie Pier can only hold out a few more years. At that point dredging will have to cease because there will be nowhere to place the materials.

Recently many shipping companies have become very concerned. They have made huge financial investments to build facilities to process and ship coal, iron ore, and grain down lake to Chicago, Detroit, Cleveland, and even to other countries. Without dredging there is no revenue.

The port needs to develop a strategy, very soon, for extending the life of Erie Pier. Shipping companies are getting nervous and they want to move this issue to the front burner. A lack of dredging in the port will cost the shippers millions of dollars in lost revenues.

\section{PORTS OF DULUTH AND SUPERIOR AND THEIR OPERATIONS}

The following is a description of the Duluth-Superior harbor taken from the 1998 Dredged Material Management Plan for the port.

The harbor is located within the confines of the cities of Duluth, MN and Superior, WI. The harbor occupies 32 square miles and has over 100 miles of waterfront. The harbor is protected by a natural barrier, a sand and gravel bar (i.e. Minnesota Point and Wisconsin Point) and just over six miles in length. The bar is transected by two entrances, The Duluth Ship Canal and the Superior Entry, both of which give access to Lake Superior.

The harbor is considered a deep draft harbor to accommodate the 1,000 foot iron ore vessels and the salt water vessels which visit the port. There are 18 miles of dredged channels in the port that are dredged to a depth of 28-32 feet at the entrance and 20-23 feet in the inner channels. The channel widths are between 250 to 3700 feet.

${ }^{1}$ Silt is a very fine powder like material that has limited commercial uses. Sand is coarse material that is in high demand by many contractors.
Dredged mateiation of both. Copyright by author(s); CC-BY 
It is among the top 20 leading ports in the United States and the leading Great Lakes port in terms of tons shipped. In 2008, almost 48 million tons of goods were shipped via the port which was valued at $\$ 2$ billion. In 2009 , in the midst of the recession, the amount of goods being shipped through the port fell considerably. Total shipments fell by almost 16.5 million tons, although shipments overseas did increase somewhat. However, shipments to Canada fell by almost 50\%. In 2012 the total tons shipped stood at 36.6 million tons. The 2012 total is still down from the peak year of 2008. As the national economy goes so goes the fortunes of the Port of Duluth/Superior. Exhibits 1, 2, and 3 provide details on shipping and the economic impact of the port.

Exhibit 1: Shipping Statistics-Tons Shipped

\begin{tabular}{|c|c|c|c|c|}
\hline Year & Total Tons Shipped & Canada Shipment & Overseas Shipment & Domestic Shipment \\
\hline 2008 & $47,858,484$ & $14,230,726$ & 858,360 & $30,663,627$ \\
\hline 2009 & $31,210,918$ & $7,308,632$ & $1,072,048$ & $22,830,238$ \\
\hline 2010 & $39,829,507$ & $9,482,786$ & $1,602,478$ & $28,744,243$ \\
\hline 2011 & $37,101,554$ & $6,708,871$ & 989,165 & $29,403,518$ \\
\hline 2012 & $36,673,052$ & $6,493,171$ & $2,160,957$ & $28,018,923$ \\
\hline
\end{tabular}

Exhibit 2: Total Vessel Traffic

\begin{tabular}{|l|c|c|c|c|}
\hline Year & Total Arrivals & Overseas Arrivals & Canadian Arrivals & Domestic Arrivals \\
\hline 2008 & 1,127 & 69 & 285 & 773 \\
\hline 2009 & 726 & 64 & 187 & 475 \\
\hline 2010 & 991 & 105 & 230 & 656 \\
\hline 2011 & 894 & 71 & 228 & 595 \\
\hline 2012 & 913 & 68 & 231 & 614 \\
\hline
\end{tabular}

Exhibit 3: Economic Impact of The Port--2010

\begin{tabular}{|l|c|}
\hline \multicolumn{1}{|c|}{ Jobs } & \\
\hline Direct & 2,985 \\
\hline Induced & 5,755 \\
\hline Indirect & 2,770 \\
\hline Total Jobs & 11,510 \\
\hline \multicolumn{1}{|c|}{ Taxsonal Income (\$1,000's) } & $\$ 142,662$ \\
\hline Direct Paid (\$1,000's) & $\$ 325,854$ \\
\hline Re-Spending 1877,186 \\
\hline Indirect & $\$ 545,701$ \\
\hline Total & $\$ 1,489,809$ \\
\hline Business Revenues (\$1,000's) & $\$ 146,280$ \\
\hline Local Purchases (\$1,00's) & $\$ 58117$ \\
\hline State Taxes & $\$ 98,226$ \\
\hline Federal Taxes & $\$ 156,343$ \\
\hline Total Taxes Paid & \\
\hline
\end{tabular}

\section{DREDGING OPERATIONS IN THE DULUTH/SUPERRIOR PORT}

Dredging in the Duluth/Superior Harbor goes back to the $19^{\text {th }}$ century. Congress authorized the construction of piers and backwaters as well as the dredging and maintenance of the necessary channels. Initially, the dredged materials were used to construct waterfront property, docks, and several islands.

Since 1980, a little over 3.5 million cubic yards of materials have been dredged from the harbor at a total cost of $\$ 21.45$ million. On the average about 115,000 cubic yards of material are dredged each year at a cost of about $\$ 650,000$ per year. Annual dredging is a function of need and federal funding. The Army Corps accesses the needs and priorities among all of the Great Lakes Ports and allocates the funding accordingly. Dredging is also a function of the silt and other materials which are washed downstream by the rivers which feed into the port. The amount is dependent on the amount of rain and snow melt off as well as the erosion which takes place along the river banks. The cost fluctuates according to how the material is dredged and where it is placed. It is far less expensive to dredge hydraulically and to pump the material to a beach for replenishment. It is more expensive to dig 
the material, load it on a barge, and transport it to Erie Pier where it is then off-loaded. An additional problem which has developed in recent years is the significant fluctuation in the water level of Lake Superior. Over the last several years the lake level has fluctuated by more than 18 inches. For a 1,000 foot coal freighter, one inch of water draft translates into a loss of 250-260 tons per ship load. With a loss of 18 inches each ship is leaving port with 4,500 tons less cargo. That requires about 45 additional ship loads to transport the same amount that can be moved when the lake is at its normal level.

Overall dredging operations are the responsibility of the ACE. The Port is the local sponsor which means they provide a place to store the dredged materials and are responsible for their ultimate disposal. In the Port of Duluth and Superior dredging can only take place in the summer. During the cold winter season much of the inner harbor is frozen over with a thick layer of ice. The materials dredged from the harbor vary from coarse sand like material which is much demand from contractors in Minnesota to silt which is much more difficult to place with contractors. The silt material is also very hard to work with. When it is dry it is very dusty and can be blown about by the wind. When it is wet, it is very heavy and difficult to work with. When it dries it becomes very hard, almost cement like.

\section{HISTORY OF ERIE PIER}

Erie Pier was constructed as part of the River and Harbor Act of 1970 (Section 123 of Public Law 91-611). The act gave the Army Corps of Engineers (ACE) the authority to construct, operate, and maintain a confined disposal facility (CDF).

The facility was constructed in 1979 on an 89 acre site donated by the Port of Duluth. The initial capacity was 1.1 million cubic yards. The initial estimated life was 10 years.

\section{ERIE PIER PLANNING: SHORT TERM AND LONG TERM}

\section{Planning Process}

All ports which receive federal money for dredging must develop a dredging plan. They are required to identify the dredging needs of the port as well as the methods which will be used to manage the dredged materials for a period of 20 years. In 1998 a number of groups came together to develop the Dredged Materials Management Plan (DMMP) for the Port of Duluth/Superior. The DMMP identified the dredging needs of the harbor and the methods of managing the materials removed from the harbor. In addition to the local authorities developing a DMMP the Corps must sign off of the plan and select the plan or alternatives which are the least costly, utilize sound engineering standards and comply with section 404 (b)(1) of the Clean Water Act. The 1998 DMMP identified three major alternatives with respect to the placement of the dredged materials. Continued beach nourishment was identified as a good alternative. Second, the DMMP identified the continuous use of Erie Pier as a place to store dredged materials as a reasonable alternative. Third, the DMMP identified the use of so called "deep holes" within the harbor as a good alternative to dispose of dredged materials.

\section{Least Cost Alternative}

The ACE took the DMMP and applied the least cost requirement and came up with an alternative approach with respect to the placement of dredged materials. The ACE felt the least cost alternative required them to use open water dumping as the primary method of disposing of dredged materials. Open water dumping is used extensively in the United States. In the case of the Duluth/Superior port, it would consist of taking the dredged materials and dumping them into Lake Superior. The major problem with open water dumping was that it violated both Minnesota and Wisconsin law. When the state authorities understood what the ACE was advocating they threatened to deny the permits required for the ACE to dump the materials.

A compromise was reached when the ACE agreed only to use open water dumping as a benchmark to determine the least cost alternative to determine total funding for dredging in the port. Open water dumping would not be utilized, but would be a base line for future funding. Likewise the ACE would not continue to pursue open 
water dumping as an alternative means of disposing dredged materials. The ACE accepted the DMMP and its 20 year plan for port dredging and disposal with several provisions. The ACE might use the dredging to create major wildlife habitat in the harbor. This would utilize up to 1,000,000 cubic yards of material (about 10 years worth). In addition the ACE would also use dredging to replenish beaches (5 years worth) and another 5 years worth of dredging materials would be placed in Erie Pier. At that point the ACE assumed Erie Pier would be full and no further modifications could be made to expand its capacity. The DMMP does not address the issue of replacing Erie Pier when it reaches its maximum capacity.

\section{Political and Economic Externalities}

A new CDF is not possible. There is no land within the Port boundaries on which to build a new facility. In addition, both the financial and political costs are astronomical. To build a new CDF the ACE estimates that it would cost approximately $\$ 30$ million. In addition, politically it may be impossible to overcome the "not in my back yard" challenge by numerous environmental groups. Erie Pier sits at the nexus of a number of agencies or groups; all of which can control or thwart both the long term and short term planning of the facility. Some of the groups are very pro-business and some are very pro-environment. A number of the groups have competing long term interests. To get a unanimous agreement all of the affected stakeholders would be almost impossible.

\section{ERIE PIER AND THE REGUALTORY ENVIRONMENT}

As previously pointed out, both Minnesota and Wisconsin prohibit the open water dumping of dredged materials in Lake Superior. In addition, there are some significant differences in how each state allows the disposal of materials dredged from the Duluth/Superior harbor.

\section{Minnesota Regulations}

Minnesota law requires that the sediment from the proposed dredge site be analyzed prior to initiating dredging activity. Likewise an environmental risk assessment must be conducted to evaluate the likelihood that a given pollutant is present in the dredged materials. The beneficial re-use of dredged materials is considered to be in the best interests of the state. Therefore, state law allows for three categories of use based on the soil reference values of the dredging (i.e. what pollutants are present, if any). Tier 1 materials (no pollutants) can be used for residential use. Tier 2 materials have insignificant amount of pollutants and can be used for industrial or recreational use. Tier 3 (some significant pollutants) requires additional regulation. The goal of Erie Pier, with respect to Minnesota law, is to place the dredged materials with a Tier 2 user. Generally, in Minnesota the only environmental risk associated with the dredged materials from Erie Pier is the potential propagation of Purple Loose Strife, a noxious and invasive weed. Its seeds can be spread in the application of dredged materials. However, a topical application of a weed killer is considered sufficient to rectify the problem.

\section{Wisconsin Regulations}

Wisconsin laws are different. Wisconsin considers dredged materials to be a solid waste and puts more stringent controls on their eventual disposal outside of a CDF. The materials can be exempted from the solid waste rules, but it must be done on a case by case basis. Applicants must document that the project will not cause violations of state environmental standards or threaten protected resources. A public meeting must be held before the state will approve the disposal of dredged materials. Some cases where dredged material has been re-used in Wisconsin include landfill daily cover, habitat protection and restoration, and construction fill utilization. Users must show that the use of these materials is not harmful to the environment.

\section{ERIE PIER POTENTIAL MARKETS, OPERATIONS, AND COSTS}

The Port of Duluth and the ACE have not been oblivious to the fact that Erie Pier is quickly filling up. They have developed a list of businesses and other entities which have expressed a significant interest in using the dredged silt from Erie Pier in their ongoing operations. The list which indicates the short term potential projects are those which can use the materials presently stored in Erie Pier. Some projects may be one time only while others 
may represent an ongoing commitment to use the materials. These are projects which can utilize the fine grain material which is more difficult to place. The challenge is to get the materials to their place of business at the least cost. Exhibit 4 summarizes the short-term potential uses of silt.

Exhibit 4: Short Term Markets

\begin{tabular}{|l|c|c|c|}
\hline \multicolumn{1}{|c|}{ Ready To Go/Short Term Potential Projects } \\
\hline \multicolumn{1}{|c|}{ Customers } & Distance/Miles & Needs/Cubic Yards & Annual Recurring \\
\hline Waste Management Elk River & 165 & 21,200 & YES \\
\hline Keewatin Taconite Mine & 85 & 8,900 & NO \\
\hline United Taconite Mine & 60 & 8,900 & NO \\
\hline MNDOT (3) & 50 & 100,000 & YES \\
\hline Waste Management Canyon & 30 & & NO \\
\hline MNDOT (2) & 25 & 50,000 & NO \\
\hline Wrenshall Farmers & 23 & 65,000 & NO \\
\hline MNDOT (1) & 10 & 25,000 & YES \\
\hline Waste Management Superior & 5 & 21,200 & \\
\hline
\end{tabular}

\section{Landfill Ground Cover}

As an example of bulk processing for materials destined for traditional landfill cover, the Waste Management, Inc. Voyageurs Industrial Landfill site in Canyon, MN accepts wood fiber "strands" or paper byproduct from the NewPage Corporation paper plant, which is shipped to them around the clock every day of the week from the Duluth plant. The facility is a clean industrial/demolition debris landfill located on a 100-acre parcel in Section 2, Township 52 North, Range 17 West, near Canyon, Minnesota (St. Louis County). Waste Management, Inc. is also shipping some NewPage material to their Elk River, MN facility. The Elk River landfill site can accept more than 70 tons daily of landfill cover and is a higher volume site than the Canyon site.

Cover for the Superior, Wisconsin landfill is both paper residue from the NewPage paper mill in Duluth and sand from a gravel pit in the City of Superior. To make a change in landfill cover materials the change would have to make financial sense to the City of Superior. The landfill uses, as a 6 inch daily cover, a mixture of $75 \%$ NewPage material and $25 \%$ sand. Waste Management, Inc. hauls the material from Duluth to Superior, and the landfill charges a tipping fee to accept the product. The landfill maintains an inventory of materials up to 1-2 days only. The tipping fee is approximately $\$ 100$ per truckload. Tipping fees are relatively new, having started within the last two years.

\section{Highway Construction}

The Minnesota DOT's Department of Materials and Research maintains the standards for project specifications. As long as materials meet specifications and testing, contractors can get them from local sources and utilize for highway construction. However, MNDOT indicated that contractors generally would not go beyond approximately 50 miles to haul materials for a work site.

However, contractors may choose not to use the coarse material from Erie Pier. In the case of dredged silt it is thought that for contractors to use Erie Pier materials, the cost of these materials would have to be a very low or free because of hauling expense.

Contractors tend to choose materials closest to the work site to keep costs down, and most contractors get their material from local sand and gravel pits. Material from these pits has to be tested. One project a MNDOT representative thought might be a possible use for Erie Pier dredged silt in the Duluth area would be embankment bridge work on I-35 at the ore docks.

\section{Farmland Enhancement}

A Minnesota Extension agent reviewed the laboratory work on the dredged silt and concluded that the material is acceptable for soil enrichment use by farmers. The transport model for farmers using silt material should figure use of Hwy 35 and Hwy 2, however, the hauling cost is the key element. 
Further discussion with Minnesota Extension included the observation that the project would need to be managed over 5 or more years, and could be worked into a land application program, with some other creative outcomes. However, operational dollars are needed to make it happen. Given the hauling costs, Extension doesn't see this project implemented without a subsidy for farmers as end-users. To this end, Minnesota Extension would be interested in working with Erie Pier to use the dredged silt.

\section{LONG TERM POTENTIAL CUSTOMERS}

The Port and the ACE have also identified several future construction projects in the immediate port area which can use enormous quantities of dredged materials. If these projects are undertaken and if future dredged materials are placed there it would allow Erie Pier to continue in operations for a great many years. The short and long term projects are independent of one another. Exhibit 7 provides details on long term potential customers.

Exhibit 7: Long Term Potential Projects

\begin{tabular}{|l|c|c|c|}
\hline \multicolumn{1}{|c|}{ Customers } & Distance/Miles & Needs/Cubic Yards & Annual Recurring \\
\hline Hibbard Power Plant & 3 & $1,000,000$ & NO \\
\hline 21 St Ave. Project & 1 & 950,000 & NO \\
\hline CN Railroad Project & 2 & 900,000 & NO \\
\hline Sky Harbor Airport & 7 & 250,000 & NO \\
\hline
\end{tabular}

The Hibbard power plant, located in the harbor, is owned by Minnesota Power. Several years ago it converted to biomass as the fuel source for this plant. It now wishes to expand operations to take advantage of a recent Minnesota law mandating that a portion of all power used in the state must come from sources other than coal or natural gas. The power generated would be sold to Minnesota Power customers throughout it area of coverage. In addition, some of the steam generated will be used to heat local buildings. Dredged materials can be used in the construction of the expansion.

The 21st Avenue project is an attempt to construct wildlife habitat using dredged materials within the confines of Duluth-Superior bay. It will offer a habitat to migrating birds as well as those that are regulars to the area. It will also create a habitat for many species of fish commonly found in Lake Superior.

The CN Railroad project is the result of a rather unusual occurrence in the Port of Duluth-Superior. Many of the steel pilings used to shore up the docks and other port infrastructure have been found to be deteriorating very quickly. Scientific research revealed that a bacterium is responsible for the structural destruction of the port's steel pilings. In an attempt to shore up the pilings used in its ore loading dock, $\mathrm{CN}$ is proposing to fill in large portions of the areas where there are exposed steel pilings around the ore loading facility. Dredged materials could be used.

The Sky Harbor project is the result of a compromise between the city of Duluth and the FAA. Initially, the FAA wanted to extend the runway and subsequently cut down some old growth timber. Many of these were old growth white pine, which is quite rare. The compromise reached is to re-orient the runway and save the old growth pine trees. This will require filling in a large area adjacent to the airport and the construction of new runway. Again, dredged materials could be used.

\section{COST ASSUMPTIONS}

The ACE operates the CDF. As such, the ACE incurs the operational cost of maintaining Erie Pier. Presently there are two operators working at the site. One operates the bulldozer and the other operates the front end loader. The ACE also incurs the capital costs of purchasing new heavy equipment when needed. The purchase price of new equipment is given in the data shown. Exhibits 5 and 6 provide details on operating costs.

Exhibit 5: Operating Cost Assumptions

\begin{tabular}{|l|c|c|}
\hline \multicolumn{1}{|c|}{ Items } & Hourly Amount & Total Amount \\
\hline Pay and Benefits & $\$ 54$ & \\
\hline Fuel & $\$ 24$ & \\
\hline Depreciation & $\$ 32$ & $\$ 110$ \\
\hline Total Per Hour & & \\
\hline
\end{tabular}


Exhibit 6: Cost Assumptions

\begin{tabular}{|l|c|}
\hline \multicolumn{1}{|c|}{ Item } & Amount \\
\hline Bulldozer Purchase Price & $\$ 200,000$ \\
\hline Front End Loader Purchase Price & $\$ 200,000$ \\
\hline Useful Life of Machines (Hours) & 12,500 hours \\
\hline Truck Rental Cost Per Hour & $\$ 100$ per hour \\
\hline Truck Hauling Capacity (cubic yards) & 18 cubic yards \\
\hline Trucks Serviced Per Hour & 4 per hour \\
\hline Loading and Unloading Time (Hours) & 0.5 hours \\
\hline
\end{tabular}

The only viable means of removing the dredging currently in Erie Pier is by truck. At present, local trucking contractors have quoted a rate of $\$ 200$ per hour to haul the materials to another site. The cost of moving the material to another location is a function of the time it takes the truck to get to its destination and return. The total time would also include any time spent loading and unloading the material. The clock would start running the moment the truck arrives at the Erie Pier site and would continue until it arrived back at its base of operations. It is estimated that it would take fifteen minutes to load the truck and another fifteen minutes to unload it. The truck can carry a load of eighteen cubic yards. Each yard of material weighs approximately one ton. While there is a rail line adjacent to the Erie Pier site it is highly unlikely a rail spur can be built in the foreseeable future. The two major impediments to building a rail spur are its cost (i.e. $\$ 5$ million) and the fact the present owner is not at all interested in selling the land needed to build the spur. For these reasons train transportation is not considered.

\section{CONCLUSION}

Dredging in the Great Lakes region has become problematic. For many ports the biggest problem is finding a place to store or dispose of materials dredged each year. In some ports the dredged materials are considered toxic. This only adds to the difficulty in finding an acceptable place to place the dredged materials. Adding to this woe is the fact that port authorities do not have the appetite to take on the financial or political cost of creating new contained disposal facilities (CDF).

The Port of Duluth/Superior is very fortunate that its dredged materials do not contain toxic or dangerous materials. They can be used in a number of industrial settings. The Port Authority has taken some time to reach a consensus with its constituent groups to find some creative disposal alternatives that all can agree on. These solutions reflect the new reality of finding a sustainable solution with no additional funding. Recently a creative solution has been the use of hydraulic dredging (at less cost) to bypass Erie Pier and place the dredged materials directly in the $21^{\text {st }}$ Avenue West Project. This sustainable project is expected to need approximately 950,000 cubic yards of material to restore a wildlife habitat in the St Louis River watershed.

\section{QUESTIONS}

1. If the intention is to extend the life of Erie Pier, what is the cost object?

2. What are the relevant costs to be considered in any decision by the Port of Duluth to move the dredged materials out of the Erie Pier facility?

3. What is the most important variable cost to be considered when it comes to moving the material out of Erie Pier?

4. Is dredging a government subsidy offered to shipping companies using the Port of Duluth?

5. Assume you have been hired as a marketing manager for Erie Pier's products. From among the list of shortterm prospects listed in the case, upon which would you focus your initial efforts? Why? From among the list of long term prospects listed in the case, upon which would you focus your initial efforts? Why?

6. Create a public press release as part of a marketing campaign that achieves the following goals: (1) inform the public how much material is dredged from the Duluth harbor, (2) inform the public of the need to safely use dredged materials rather than simply store it at Erie Pier, (3) inform the public that dredged materials meet MNDOT's highway construction materials standards, (4) encourage the public to encourage, by whatever means at their disposal, the use of dredged materials for highway construction projects. The press release will be sent to all regional news outlets. Ultimately, it is hoped that the press release will encourage highway construction contractors to desire to use the dredged materials. 
7. Should the States of Minnesota and Wisconsin mandate that State agencies use Eire Pier dredged materials on State funded projects such as DNR land reclamation or MNDOT and WISDOT road construction?

8. Are the current Eire Pier site re-use costs so high that creating a new site is a better long-term economic alternative?

9. Is purple loose strife a major contamination issue for potential contractors?

10. Since transportation costs are a barrier to Eire Pier dredged materials being re-used, should the US Army Corps of Engineers or the States of Minnesota and Wisconsin subsidize truck and rail costs?

11. Assume you will make a sales presentation to the Senior Operations Manager for the Superior, Wisconsin landfill. Your goal is to have her approve the use of dredged materials for landfill cover. Outline the key points you intend to make during that presentation, and list 4 objections you might expect to hear and provide helpful answers for each.

\section{AUTHOR INFORMATION}

Rodger L. Brannan, Ph.D., is an associate professor of accounting in the Labovitz School of Business and Economics at the University of Minnesota Duluth. He also holds a CPA certificate from the State of Indiana. His current research interests include government and not for profit, accounting and business history, and cost and strategy. He has published in Public Budgeting and Finance, Public Productivity and Management Review, International Journal of Accounting, American Academy of Accounting and Finance, and Administration Journal. E-mail: rbrannan@d.umn.edu

James A. Skurla, MA, is currently the Director of the Bureau of Business and Economic Research (BBER) at the University of Minnesota Duluth. Jim has almost 30 years of work experience in economic development. As Director of the BBER, he conducts and supervises grant and contract regional economic and business research. When Jim was a Business Development Specialist at UMD's Natural Resources Research Institute Business Group, he worked with business development for aquaculture, wood, peat, and clay products. Jim has expertise in business plans, economic impact and feasibility studies, business assessments, and loan packaging. E-mail: jskurla@d.umn.edu

Stephen B. Castleberry, Ph.D., has been a Professor of Marketing in the Labovitz School of Business and Economics at the University of Minnesota Duluth since 1992, where he teaches marketing and business ethics courses. Prior to joining UMD he held positions at Northern Illinois University (UARCO Professor of Sales and Marketing endowed chair) and the University of Georgia. He has also held administrative posts at both NIU and UMD. Dr. Castleberry has published in many refereed journal articles in national publications, is the co-author of Selling: Building Partnerships, and is the past marketing editor of the Journal of Applied Business Research. Email: scastleb@d.umn.edu (Corresponding author)

\section{REFERENCES}

1. Association of American Railroads, Policy and Economics Department. (2008, May). Overview of America's freight railroads.

2. Crane, J. L. Environmental Outcomes Division Minnesota Pollution Control Agency United States Great Lakes National Program Office. EPA assessment of contaminated sediments in slip C Duluth Harbor, Minnesota. EPA-905-R-99-007.

3. Duluth-Superior Metropolitan Interstate Council. (2007, June). Erie Pier Management Plan. Prepared by the Duluth and Superior urban area communities cooperating in planning and development through a joint venture of the Arrowhead Regional Development Commission and the Northwest Regional Planning Commission Duluth-Superior.

4. $\quad$ Eger, P., et al. (2000, January). Minnesota Department of Natural Resources, Division of Lands and Minerals. The use of dredge material as an organic substrate to create wetlands in Taconite Tailings Basins, Final Report.

5. Great Lakes Commission, Beneficial Use Upland Testing and Evaluation Project Management Team. (2004). Testing and evaluating dredged material for upland beneficial uses: A regional framework for the Great Lakes. Retrieved from http://www.glc.org/upland/ download/ UplandFramework_2.pdf 
6. Minnesota Department of Natural Resources. Division of Lands and Minerals. (2004, April). Biosolids for reclaiming minelands. MN DNR: Hibbing, MN. Retrieved from http://files.dnr.state.mn.us/lands_minerals/biosolids\%20report_all.pdf

7. Minnesota Pollution Control Agency. (2007, Oct) Industrial Division, Land and Water Quality Permits. Waste Water General \#2.01. Managing Dredged Materials in the State of Minnesota.

8. Mozol, A., Duluth Area Office, and Ross, P., P. E., USACE, Detroit District, United States Army Corps of Engineers. (2007, June). Regional sediment management beneficial reuse of dredged sediment Erie Pier management plan Duluth, Minnesota.

9. $\quad$ Myers, J. (2013, April 30). Dredging crisis affects Great Lakes. Duluth News Tribune.

10. Olin-Estes, T. J., \& Palermo, M. R. (2001). Recovery of dredged material for beneficial use: The future role of physical separation processes. Journal of Hazardous Materials, 85(1-2), 39-51.

11. Pebbles, V., \& Dettling, J. (2004, April 13). A regional framework for testing, evaluation, and planning for upland beneficial uses of dredged material. Great Lakes Commission. GLDT Meeting, Cleveland. GLC: Ann Arbor, MI. Retrieved from http://www.glc.org/upland/

12. Sediments Treatment - Erie Pier, Duluth. ECP ElectroChemical Remediation Technologies. Retrieved from www.ecp- int.com and www.electropetroleum.com

13. Simonson, M. (2013, August 11). Dredging getting underway in the Twin Ports, New use for wet dirt. Business North. Retrieved from http://www.businessnorth.com/kuws.asp?RID=4903

14. United States Army Corps of Engineers. (1999, April). Dredged Material Management Plan (DMMP) for the Duluth Superior Harbor.

15. U.S. Army Corps of Engineers. U.S. Army Engineer Research and Development Center. (2003, January). Evaluation of dredged material proposed for disposal at Island, Nearshore, or Upland confined disposal facilities - Testing Manual. USACE: Washington, DC.

16. United States Army Corps of Engineers. (2007, September). Final sampling results report Erie Pier Confined Disposal Facility Duluth Minnesota. Prepared by PKS Polu Kai Services, Falls Church, Virginia.

17. U.S. Environmental Protection Agency, and U.S. Army Corps of Engineers. (2007, October). Identifying, planning, and financing beneficial use projects using dredged material; beneficial use planning Manual. EPA: Washington, DC EPA842-B-07-001. Retrieved from http://www.glc.org/dredging/benuse/documents/BeneficialUseManual002.pdf

18. United States General Accounting Office. Railroad regulation, changes in freight railroad rates from 1997 through 2000, GAO-02-524.

19. Water Resources Development Act of 2007. Public Law 110-114. Sec. 3093. Duluth Harbor, Minnesota; and Sec. 5014. Great lakes Navigation and Protection, including Partnering agreements for dredged material processing, treatment, contaminant reduction or disposal.

20. Western Lake Superior Sanitary District. (2007). Biosolids Master Plan.

21. United States Army Corps of Engineers, Detroit District Project Operations Section. (2007, January 8). Annual Report/Contract Dredging Report. 